\title{
Distinguishing Conventional and Distonic Radical Cations by Using Dimethyl Diselenide
}

\author{
Kami K. Thoen, Brandon J. Beasley, Rebecca L. Smith, and \\ Hilkka I. Kenttämaa \\ Department of Chemistry, Purdue University, West Lafayette, Indiana, USA
}

Dimethyl diselenide is demonstrated to be among the most powerful reagents used to
identify distonic radical cations. Most such ions readily abstract $\mathrm{CH}_{3} \mathrm{Se}$ from dimethyl
diselenide. The reaction is faster and more exclusive than $\mathrm{CH}_{3} \mathrm{~S}^{\circ}$ abstraction from dimethyl
disulfide, a reaction used successfully in the past to identify numerous distonic ions. Very
acidic distonic ions, such as $\mathrm{HC}^{+}(\mathrm{OH}) \mathrm{OCH}_{2}$, do not undergo $\mathrm{CH}_{3} \mathrm{Se}^{\circ}$ abstraction, but instead
protonate dimethyl diselenide. In sharp contrast to the reactivity of distonic ions, most
conventional radical cations were found either to react by exclusive electron transfer or to be
unreactive toward dimethyl diselenide. Hence, this reagent allows distinction of distonic and
conventional isomers, which was demonstrated directly by examining two such isomer pairs.
To be able to predict whether electron transfer is exothermic (and hence likely to occur), the
ionization energy of dimethyl diselenide was determined by bracketing experiments. The
low value obtained ( $(7.9 \pm 0.1$ eV) indicates that dimethyl diselenide will react with many
conventional carbon-, sulfur-, and oxygen-containing radical cations by electron transfer.
Nitrogen-containing conventional radical cations were found either to react with dimethyl
diselenide by electron transfer or to be unreactive. () 1996 American Society for Mass
Spectrometry (J Am Soc Mass Spectrom 1996, $7,1245-1250)$

$\mathrm{K}$ nowledge concerning the structures of organic radical cations is crucial for numerous applications of mass spectrometry, ranging from attempts to advance the fundamental understanding of ionic gas-phase processes to interpretation of unknown mass spectra. Many conventional organic radical cations (e.g., molecular ions) have been demonstrated to isomerize to a distonic ion (formally an ionized biradical, zwitterion, or ylide) [1]. Hence, a simple method that would allow the unambiguous identification of distonic ions would be invaluable.

Dimethyl disulfide is among the reagents commonly used [2] to identify distonic ions. Most such ions react with $\mathrm{CH}_{3} \mathrm{SSCH}_{3}$ by $\mathrm{CH}_{3} \mathrm{~S}^{\circ}$ abstraction while conventional radical cations either react by electron transfer or are unreactive. This approach is not universally applicable, however. Some distonic ions react with $\mathrm{CH}_{3} \mathrm{SSCH}_{3}$ by electron transfer in addition to $\mathrm{CH}_{3} \mathrm{~S}$ ' abstraction. For example, ${ }^{\circ} \mathrm{CH}_{2} \mathrm{CH}_{2} \mathrm{CH}_{2} \mathrm{CO}^{+}$ reacts with $\mathrm{CH}_{3} \mathrm{SSCH}_{3}$ by these two pathways in about a 1:1 ratio [2]. The observation of electron transfer complicates the interpretation of the data because it is unknown whether the species undergoing this reaction is a distonic ion or whether part of the ion population

Address reprint requests to Dr. Hilkka Kenttämaa, Department of Chemistry, Purdue University, 1393 Herbert C. Brown Laboratory of Chemistry, West Lafayette, IN 47907-1393. has a conventional structure. Further complications arise from the facts that many distonic ions are unreactive toward $\mathrm{CH}_{3} \mathrm{SSCH}_{3}$, and that those ions that do undergo $\mathrm{CH}_{3} \mathrm{~S}^{\circ}$ abstraction react only slowly (usually less than one of five collisions leads to $\mathrm{CH}_{3} \mathrm{~S}^{\circ}$ abstraction) [2-4].

As an attempt to address the foregoing problems, dimethyl diselenide was recently examined [5] as an alternative reagent for identifying distonic ions. We provide here a comprehensive evaluation of the effectiveness of $\mathrm{CH}_{3} \mathrm{SeSeCH}_{3}$ as a tool for distinguishing distonic and conventional radical cations, and examine the advantages of the use of this reagent over the use of $\mathrm{CH}_{3} \mathrm{SSCH}_{3}$. Finally, the ionization energy of dimethyl diselenide was determined. This value allows one to predict when electron transfer reactions are to be expected.

\section{Experimental}

All compounds used were obtained from Aldrich Chemical Co. (Milwaukee, WI) and used as received, with the exception of dimethyl diselenide (a toxic chemical), which was purified by vacuum distillation at 0.1 torr (b.p. $156^{\circ} \mathrm{C}$ ). The purity of all reagents was checked by gas chromatography and by mass spectrometry. 
The experiments were carried out in an Extrel FTMS/2001 Fourier transform ion cyclotron resonance mass spectrometer (Finnigan FTMS, Madison, WI). This instrument contains a dual cell that consists of two identical cubic 2 -in. cells joined by a common wall (the conductance limit). The cell is aligned collinearly within the magnetic field produced by a $3.0-\mathrm{T}$ superconducting magnet operated at approximately $2.5 \mathrm{~T}$. The conductance limit and the two end trapping plates were held at $+2.0 \mathrm{~V}$ to trap positive ions within the cell. The cell was differentially pumped with two Balzer (Arlington Heights, IL) turbomolecular pumps $(330 \mathrm{~L} / \mathrm{s})$, each of which was backed with an Alcatel (Hingham, MA) 2012 mechanical pump. A nominal base pressure of $<1 \times 10^{-9}$ torr was maintained within the cell, as read with two ion gauges.

Samples were introduced into the instrument by using two Extrel single batch inlet systems equipped with a variable leak valve (nominal pressures $=1.0 \times$ $10^{-7}$ torr). Before introduction into the cell, dimethyl diselenide was degassed several times by freezing the sample with liquid nitrogen, pumping away the air, and allowing the sample to warm up to room temperature. The reactant ions were generated in one side of the dual cell by electron ionization or by ion-molecule reactions. The ion signal was optimized by varying the electron beam time (30-70 ms), emission current (3-8 $\mu \mathrm{A})$, electron energy $(20-70 \mathrm{eV})$, and reaction time. All ions were removed from the other cell region by changing its end trapping plate voltage from +2.0 to $-2.0 \mathrm{~V}$ for $10-15 \mathrm{~ms}$. The ions were transferred into this cell region by grounding the conductance limit plate for approximately $100 \mu \mathrm{s}$. The ions were cooled by collisions with argon introduced into the instrument through a pulsed-valve system. All unwanted ions were ejected by applying stored waveform inverse Fourier transform (SWIFT) [6] excitation pulses to the excitation plates by using an Extrel SWIFT module. The isolated ion was then allowed to react with neutral reagents for a variable period of time. Each reaction spectrum was background corrected by using a previously described procedure [7].

The product ions were excited for detection by applying an excitation sweep of $124-\mathrm{V}_{\mathrm{p}-\mathrm{p}}$ amplitude, 2.7- $\mathrm{MHz}$ bandwidth, and $3.2-\mathrm{kHz} / \mu$ s sweep rate or by the SWIFT method (17-800 u, $0.5-\mathrm{cm}$ radius for all ions). A minimum of 20 acquisitions were signal averaged to improve the signal-to-noise ratio. The spectra were recorded as $32 \mathrm{k}$ data points, by using one zero fill prior to Fourier transformation.

The pressure gradient between the ion gauges and the cell must be accounted for when estimating the actual pressure in the cell [8a]. The sensitivity of the ion gauges toward different neutral reagents also varies [8b]. To compensate for these differences, an ion gauge correction factor was obtained by measuring the rates of several proton and/or electron transfer reactions with known rate constants involving each neutral reagent. The ion gauge correction factor used in the calculation of rate constants for the reactions involving neutral dimethyl diselenide is $\mathbf{1 . 8}$.

Reaction rate constants $\left(k_{\text {exp }}\right)$ were determined from plots of $\ln$ (relative reactant ion abundance) as a function of reaction time. Collision rate constants $\left(k_{\text {coll }}\right)$ were calculated by using a literature procedure [9]. The polarizability of dimethyl diselenide (necessary for the calculation of $k_{\text {coll }}$ ) was estimated to be $12.32 \AA^{3}$ [10]. The reaction efficiency is given by $k_{\text {exp }} / k_{\text {coll }}$. Primary products were identified based on their fixed relative abundances at short reaction times.

\section{Results and Discussion}

\section{Reactivity}

In relation to the sulfur-sulfur bond in $\mathrm{CH}_{3} \mathrm{SSCH}_{3}$, the relatively large outer orbitals of selenium cause the $\mathrm{Se}-\mathrm{Se}$ homolytic bond dissociation energy to be lower [11], thereby allowing this bond to be readily cleaved. Indeed, the distonic ions studied show a more efficient abstraction of a $\mathrm{CH}_{3} \mathrm{Se}^{\prime}$ group from $\mathrm{CH}_{3} \mathrm{SeSeCH}_{3}(\mathrm{Ta}$ ble 1) than $\mathrm{CH}_{3} \mathrm{~S}^{\circ}$ from $\mathrm{CH}_{3} \mathrm{SSCH}_{3}$. For example, $\mathrm{CH}_{2} \mathrm{CH}_{2} \mathrm{CH}_{2} \mathrm{CO}^{+}$(ionized cyclobutanone), an ion that has been well-characterized by theoretical and experimental methods [2, 12], reacts with $\mathrm{CH}_{3} \mathrm{SeSeCH}_{3}$ by a rapid and exclusive $\mathrm{CH}_{3} \mathrm{Se}$ abstraction (Table 1). This distonic ion reacts only slowly with $\mathrm{CH}_{3} \mathrm{SSCH}_{3}$, yielding the electron transfer product $\left(\mathrm{CH}_{3} \mathrm{SSCH}_{3}^{+\cdot}\right)$ as well as the structurally characteristic $\mathrm{CH}_{3} \mathrm{~S}^{\circ}$ abstraction product. Furthermore, the aromatic distonic ions $\mathrm{N}$-(3-dehydrophenyl)-3-fluoropyridinium ion (Figure 1a) and 4-dehydrophenyldimethyl sulfonium ion react with $\mathrm{CH}_{3} \mathrm{SeSeCH}_{3}$ by $\mathrm{CH}_{3} \mathrm{Se}$ abstraction approximately three times faster than they react with $\mathrm{CH}_{3} \mathrm{SSCH}_{3}$ (the reaction efficiencies are 25 and $14 \%$ versus 7 and $5 \%$, respectively; Table 1). Similarly, the prototypical organophosphorus distonic ion ${ }^{\circ} \mathrm{CH}_{2} \mathrm{PH}_{3}^{+}$ reacts with $\mathrm{CH}_{3} \mathrm{SeSeCH}_{3}$ by exclusive $\mathrm{CH}_{3} \mathrm{Se}^{\circ}$ abstraction at $75 \%$ of the collision rate (Figure 1c; Table 1), whereas the reaction with $\mathrm{CH}_{3} \mathrm{SSCH}_{3}$ yields both the electron transfer and $\mathrm{CH}_{3} \mathrm{~S}^{\circ}$ abstraction products (at $40 \%$ of the collision rate) [13].

The facile $\mathrm{CH}_{3} \mathrm{Se} \cdot$ abstraction observed for distonic ions can be used to distinguish them from their conventional isomers. For example, while the ion ${ }^{\circ} \mathrm{CH}_{2} \mathrm{PH}_{3}^{+}$reacts with $\mathrm{CH}_{3} \mathrm{SeSeCH}_{3}$ by $\mathrm{CH}_{3} \mathrm{Se}$ ' abstraction, its conventional isomer $\mathrm{CH}_{3} \mathrm{PH}_{2}^{+\cdot}$ yields only the electron transfer product (Table 2) [13]. Similarly, electron transfer is the only reaction observed for the conventional radical cation of trimethylene oxide, while its ring-opened distonic form ${ }^{~} \mathrm{CH}_{2} \mathrm{CH}_{2} \mathrm{OCH}_{2}^{+}$yields several products, including that formed by $\mathrm{CH}_{3} \mathrm{Se}$. abstraction (Tables 1 and 2). Some of the product ions formed upon $\mathrm{CH}_{3} \mathrm{Se}{ }^{\circ}$ abstraction from this distonic ion are unstable and spontaneously lose $\mathrm{CH}_{2} \mathrm{O}$. The same applies to the lower homolog $\mathrm{CH}_{2} \mathrm{OCH}_{2}^{+}$(Table 1). Similarly, loss of $\mathrm{CH}_{2} \mathrm{O}$ has been reported for the 
Table 1. Reactions of distonic ions with dimethyl diselenide

\begin{tabular}{|c|c|c|c|}
\hline Distonic ion & Product ion ${ }^{a}$ & Observed reaction & Reaction efficiency (\%) \\
\hline$m / 270$ & $m / 2165$ & $\mathrm{CH}_{3} \mathrm{Se} \cdot$ abstraction (100\%) & 64 \\
\hline$m /$ & $\mathrm{m} / 2109$ & $\mathrm{CH}_{3} \mathrm{Se}$ abstraction- $\mathrm{OCH}_{2}(100 \%)$ & 100 \\
\hline$m / z$ & $m / z 163$ & $\mathrm{CH}_{3} \mathrm{Se} \cdot$ abstraction $(100 \%)$ & 66 \\
\hline$m / z 60$ & $m / z 191$ & proton transfer $(100 \%)$ & b \\
\hline$m / z^{+} 58$ & 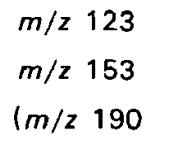 & $\begin{array}{l}\mathrm{CH}_{3} \mathrm{Se} \text { abstraction- } \mathrm{OCH}_{2}(45 \%) \\
\mathrm{CH}_{3} \mathrm{Se} \text { abstraction }(55 \%) \\
\text { electron transfer) }\end{array}$ & b \\
\hline $\begin{array}{c}\mathrm{H}_{2} \dot{\mathrm{C}}-\stackrel{+}{\mathrm{P}} \mathrm{H}_{3} \\
m / z 48\end{array}$ & $m / 2143$ & $\mathrm{CH}_{3} \mathrm{Se} \cdot$ abstraction (100\%) & 68 \\
\hline$m / z 17$ & $m / z 268$ & $\mathrm{CH}_{3} \mathrm{Se} \cdot$ abstraction (100\%) & 25 \\
\hline$\prod_{m / 2} \stackrel{+}{s} 1$ & $m / z 233$ & $\mathrm{CH}_{3} \mathrm{Se} \cdot$ abstraction (100\%) & 14 \\
\hline
\end{tabular}

The ion containing the major isotope of Se is indicated.

bast reaction.

'Trace.

$\mathrm{CH}_{3} \mathrm{~S}^{\circ}$ abstraction products formed from these two ions upon reaction with $\mathrm{CH}_{3} \mathrm{SSCH}_{3}$ [2].

The only distonic ion that does not show $\mathrm{CH}_{3} \mathrm{Se}$. abstraction is the acidic distonic ion $\mathrm{HC}^{+}(\mathrm{OH}) \mathrm{OCH}_{2}$. This ion reacts with $\mathrm{CH}_{3} \mathrm{SeSeCH}_{3}$ by proton transfer (Table 1; the same reaction has been reported [2] for $\mathrm{CH}_{3} \mathrm{SSCH}_{3}$ ). The reactivity demonstrated by $\mathrm{HC}^{+}(\mathrm{OH}) \mathrm{OCH}_{2}$, although not similar to that described above for other distonic ions, nevertheless distinguishes this ion from conventional radical cations whose reactivity is quite different, as discussed above and in subsequent text.

In sharp contrast to the behavior observed for distonic radical cations, most conventional radical cations react with $\mathrm{CH}_{3} \mathrm{SeSeCH}_{3}$ by electron transfer (Table 2). Two ions hold exception to this observation. The conventional radical cations $\left(\mathrm{CH}_{3}\right)_{3} \mathrm{P}^{+-}$and $\left(\mathrm{CH}_{3} \mathrm{O}\right)_{3} \mathrm{P}^{+-}$ have been reported to react with $\mathrm{CH}_{3} \mathrm{SeSeCH}_{3}$ by $\mathrm{CH}_{3} \mathrm{Se}^{\circ}$ abstraction (Table 2) [14]. Analogously, $\mathrm{CH}_{3} \mathrm{~S}^{\circ}$ abstraction occurs upon reaction of these ions with $\mathrm{CH}_{3} \mathrm{SSCH}_{3}$ [14]. A two-step mechanism has been used to rationalize [14] this reactivity. Electron transfer between the radical cations and $\mathrm{CH}_{3} \mathrm{SeSeCH}_{3}$ (or $\mathrm{CH}_{3} \mathrm{SSCH}_{3}$ ) is thought to lead to a long-lived ion-molecule complex wherein $\mathrm{CH}_{3} \mathrm{SeSeCH}_{3}^{+\cdot}$ (or $\mathrm{CH}_{3} \mathrm{SSCH}_{3}^{++}$) suffers a nucleophilic attack by the neutral phosphorus compound to generate the observed ionic product [14]. In support of this mechanism, $\left(\mathrm{CH}_{3}\right)_{3} \mathrm{P}$ and $\left(\mathrm{CH}_{3} \mathrm{O}\right)_{3} \mathrm{P}$ were shown to replace $\mathrm{CH}_{3} \mathrm{~S}$. in $\mathrm{CH}_{3} \mathrm{SSCH}_{3}^{+}$. The fact that the recombination energies of $\left(\mathrm{CH}_{3}\right)_{3} \mathrm{P}^{+\cdot}$ and $\left(\mathrm{CH}_{3} \mathrm{O}\right)_{3} \mathrm{P}^{+\cdot}$ are close to the ionization energies of $\mathrm{CH}_{3} \mathrm{SeSeCH}_{3}$ and $\mathrm{CH}_{3} \mathrm{SSCH}_{3}$, together with the nucleophilic character of the neutral phosphorus compounds, makes the observed reactivity possible (the ionization energies of $\left(\mathrm{CH}_{3}\right)_{3} \mathrm{P}$ and $\left(\mathrm{CH}_{3} \mathrm{O}\right)_{3} \mathrm{P}$ are 8.06 and $8.5 \mathrm{eV}$, respectively [15]). This reactivity is not expected for most organic radical cations [14]. 

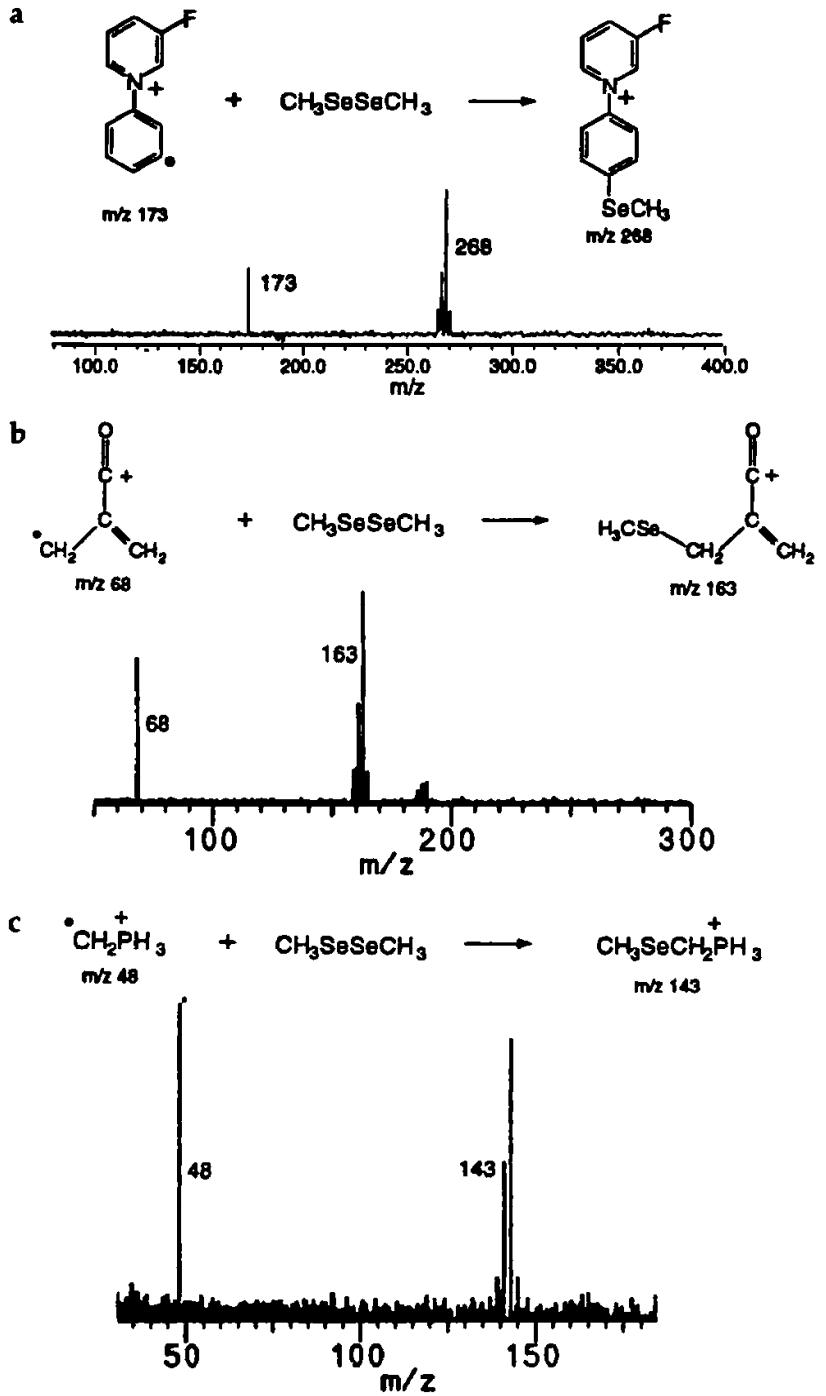

Figure 1. (a) Reaction of the N-(3-dehydrophenyl)-3-fluoropyridinium ion $(m / z 173)$ for $6.5 \mathrm{~s}$ with dimethyl diselenide (nominal pressure $9.5 \times 10^{-8}$ torr). $\mathrm{CH}_{3} \mathrm{Se}$ abstraction was observed. (b) Reaction of ${ }^{\circ} \mathrm{CH}_{2} \mathrm{C}\left(\mathrm{CH}_{2}\right) \mathrm{C}^{+} \mathrm{O}(m / z$ 68) for $1.2 \mathrm{~s}$ with dimethyl diselenide (nominal pressure $1.2 \times 10^{-7}$ torr). $\mathrm{CH}_{3} \mathrm{Se}$. abstraction observed. (c) Reaction of ${ }^{\circ} \mathrm{CH}_{2} \mathrm{PH}_{3}^{+}(m / z 48)$ for $1.6 \mathrm{~s}$ with dimethyl diselenide (nominal pressure $4.6 \times 10^{-8}$ torr). $\mathrm{CH}_{3} \mathrm{Se}$ abstraction was observed.

The occurrence of $\mathrm{CH}_{3} \mathrm{Se}^{\cdot}$ abstraction for distonic ions but not for analogous even-electron ions provides strong support for bond formation at the radical site upon $\mathrm{CH}_{3} \mathrm{Se}$ abstraction. For example, the evenelectron ions $\mathrm{N}$-phenyl-3-fluoropyridinium and $\mathrm{CH}_{3} \mathrm{CH}_{2} \mathrm{CH}_{2} \mathrm{CO}^{+}$are unreactive toward $\mathrm{CH}_{3} \mathrm{SeSeCH}_{3}$, while the related distonic ions, $\mathrm{CH}_{2} \mathrm{CH}_{2} \mathrm{CH}_{2} \mathrm{CO}^{+}$and $\mathrm{N}$-(3-dehydrophenyl)-3fluoropyridinium ion, undergo $\mathrm{CH}_{3} \mathrm{Se}$ abstraction (Table 1, Figure 1a).

\section{Ionization Energy}

Data concerning the adiabatic ionization energy of $\mathrm{CH}_{3} \mathrm{SeSeCH}_{3}$ is necessary to be able to predict which radical cations will react with this reagent by electron transfer. An approximate ionization energy of $8.1 \mathrm{eV}$ has been determined for $\mathrm{CH}_{3} \mathrm{SeSeCH}_{3}$ by photoelectron spectroscopy $[15,16]$. Bracketing experiments were employed to obtain another estimate for the adiabatic ionization energy of $\mathrm{CH}_{3} \mathrm{SeSeCH}_{3}$.

Neutral $\mathrm{CH}_{3} \mathrm{SeSeCH}_{3}$ was reacted with conventional reference radical cations of known structures and recombination energies (ionization energies of the corresponding neutral molecules) ranging between 7.1 and $9.7 \mathrm{eV}[15,17]$. Since endothermic processes cannot occur under the conditions employed here, the occurrence of electron transfer implies that the reaction is thermoneutral or exothermic. The observation of electron transfer from $\mathrm{CH}_{3} \mathrm{SeSeCH}_{3}$ to ionized 1-methylpyrrole indicates that the ionization energy of $\mathrm{CH}_{3} \mathrm{SeSeCH}_{3}$ is less than $7.94 \mathrm{eV}$ (Table 3). On the other hand, the ionization energy of $\mathrm{CH}_{3} \mathrm{SeSeCH}_{3}$ is concluded to be greater than $7.82 \mathrm{eV}$ based on the absence of electron transfer between $\mathrm{CH}_{3} \mathrm{SeSeCH}_{3}$ and ionized trimethylamine (Table 3). The bracketing of the ionization energy of $\mathrm{CH}_{3} \mathrm{SeSeCH}_{3}$ between 7.82 and $7.94 \mathrm{eV}$ was probed by examination of reactions of several other reference ions. All the conventional radical cations that were observed to undergo electron transfer with $\mathrm{CH}_{3} \mathrm{SeSeCH}_{3}$ have a recombination energy greater than $7.94 \mathrm{eV}$, and those that do not react by electron transfer have a recombination energy less than $7.82 \mathrm{eV}$ (Table 3).

The accuracy of the preceding findings was confirmed by examination of the reverse reactions (Table 3). In these experiments, $\mathrm{CH}_{3} \mathrm{SeSeCH}_{3}$ was ionized and reacted with the neutral precursors of the reference radical cations. In agreement with the above results, $\mathrm{CH}_{3} \mathrm{SeSeCH}_{3}^{+\cdot}$ reacts by electron transfer with trimethylamine, but not with 1-methylpyrrole. All the neutral compounds that were found to undergo electron transfer with $\mathrm{CH}_{3} \mathrm{SeSeCH}_{3}^{+\cdot}$ have an ionization energy less than $7.82 \mathrm{eV}$, and those that do not show electron transfer have an ionization energy greater than $7.94 \mathrm{eV}$ (Table 3). Hence, the adiabatic ionization energy of $\mathrm{CH}_{3} \mathrm{SeSeCH}_{3}$ is concluded to be $7.9 \pm 0.1 \mathrm{eV}$ and $\Delta H_{\mathrm{f}}\left(\mathrm{CH}_{3} \mathrm{SeSeCH}_{3}^{+\cdot}\right)=193 \mathrm{kcal} / \mathrm{mol}$ (the latter value is $4 \mathrm{kcal} / \mathrm{mol}$ lower than the previously reported value) [15].

\section{Conclusions}

Nonacidic distonic ions were demonstrated to abstract $\mathrm{CH}_{3} \mathrm{Se} \cdot$ from $\mathrm{CH}_{3} \mathrm{SeSeCH}_{3}$ more rapidly and more exclusively than they abstract $\mathrm{CH}_{3} \mathrm{~S}^{-}$from $\mathrm{CH}_{3} \mathrm{SSCH}_{3}$, a reagent commonly employed to identify distonic ions in the gas phase. Hence, $\mathrm{CH}_{3} \mathrm{SeSeCH}_{3}$ provides a more generally useful tool for the identification of distonic ions. The adiabatic ionization energy of $\mathrm{CH}_{3} \mathrm{SeSeCH}_{3}$ was bracketed to be $7.9 \pm 0.1 \mathrm{eV}$. Since the typical range of ionization energies encountered for carbon-, oxygen- and sulfur-containing organic compounds is $8-10 \mathrm{eV}$, electron transfer is expected to 
Table 2. Reactions of conventional radical cations with dimethyl diselenide

\begin{tabular}{|c|c|c|}
\hline Conventional ion & Product ion $^{a}$ & Observed reaction \\
\hline 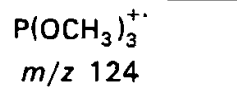 & $m / z 219$ & $\mathrm{CH}_{3} \mathrm{Se} \cdot$ abstraction (100\%) \\
\hline $\begin{array}{l}\mathrm{P}_{\left(\mathrm{CH}_{3}\right)_{3}^{+}}^{+} \\
m / 276\end{array}$ & $m / z 171$ & $\mathrm{CH}_{3} \mathrm{Se} \cdot$ abstraction (100\%) \\
\hline $\begin{array}{l}\mathrm{CH}_{3} \mathrm{PH}_{2}^{+\cdot} \\
\mathrm{m} / z 48\end{array}$ & $\mathrm{~m} / \mathrm{z} 190$ & Electron transfer $(100 \%)$ \\
\hline $\begin{array}{l}\mathrm{CH}_{3} \mathrm{SCH}_{3}^{+\cdot} \\
m / 262\end{array}$ & $m / z 190$ & Electron transfer $\{100 \%\}$ \\
\hline$\underbrace{+\cdot}_{m / 2}-\mathrm{OCH}_{3}$ & $m / z 190$ & Electron transfer $(100 \%)$ \\
\hline$=0$ & $m / 2190$ & Electron transfer $(100 \%)$ \\
\hline$\sum_{m / z 58}^{0}$ & $m / z 190$ & Electron transfer $(100 \%)$ \\
\hline$\underbrace{\mathrm{N}-\mathrm{CH}_{3}}_{m / 2}$ & $\mathrm{~m} / \mathrm{z} 190$ & Electron transfer $(100 \%)$ \\
\hline$\underbrace{}_{m / 2}+\operatorname{SCH}_{3}$ & $m / 2190$ & Electron transfer $(100 \%)$ \\
\hline$\underbrace{N-H}_{m / 2}$ & $m / z 190$ & Electron transfer $(100 \%)$ \\
\hline$\underbrace{}_{m / 2}+\mathrm{N}\left(\mathrm{CH}_{3}\right)_{2}$ & None & No reaction \\
\hline$\underbrace{}_{m / 293}+\mathrm{NH}_{2}$ & None & No reaction \\
\hline $\begin{array}{l}\mathrm{N}\left(\mathrm{CH}_{3}\right)_{3}^{+\cdot} \\
m / 259\end{array}$ & None & No reaction \\
\hline
\end{tabular}

The ion containing the major isotope of Se is indicated. 
Table 3. Bracketing of the ionization energy of dimethyl diselenide

\begin{tabular}{lccc}
\hline Neutral molecule & $\begin{array}{c}\text { Adiabatic ionization } \\
\text { energy }\end{array}$ (eV) & $\mathrm{M}^{+\cdot}+\mathrm{CH}_{3} \mathrm{SeSeCH}_{3}$ & $\mathrm{CH}_{3} \mathrm{SeSeCH}_{3}^{++} \mathrm{M}$ \\
\hline \hline Trimethylene oxide & $9.668 \pm 0.005$ & $+^{\mathrm{b}}$ & $-^{\mathrm{c}}$ \\
Cyclopentanone & $9.25 \pm 0.01$ & + & - \\
Methyl phosphine & $9.12 \pm 0.07$ & + & $\mathrm{d}$ \\
Dimethyl sulfide & $8.69 \pm 0.01$ & + & - \\
Anisole & $8.21 \pm 0.02$ & + & - \\
Piperidine & $8.05 \pm 0.05$ & + & - \\
Thioanisole & $7.94 \pm 0.02$ & + & - \\
1-Methylpyrrole & $7.94 \pm 0.02$ & - & + \\
Trimethylamine & $7.82 \pm 0.06$ & - & + \\
Aniline & $7.67 \pm 0.03$ & - & + \\
N,N-Dimethylaniline & $7.12 \pm 0.02$ & & \\
\hline
\end{tabular}

${ }^{a}$ Reference 15 unless otherwise noted.

bhe plus $(+)$ indicates that an electron transfer reaction was the only reaction observed.

c The minus $(-)$ indicates that no reaction was observed.

deaction not examined.

${ }^{\circ}$ Reference 17.

dominate the reaction of the conventional radical cations of these compounds with $\mathrm{CH}_{3} \mathrm{SeSeCH}_{3}$. Indeed, most of the conventional radical cations examined were found to react with $\mathrm{CH}_{3} \mathrm{SeSeCH}_{3}$ by electron transfer.

\section{Acknowledgments}

The National Science Foundation (CHE-9409644), the Purdue Research Foundation and the Clare Booth Luce Foundation (for predoctoral fellowships given to R. L. S.), the Eli Lilly and Company, and the Lubrizol Corporation are thanked for financial support of this work.

\section{References}

1. (a) Hammerum, S. Mass Spectrom. Rev. 1988, 7, 123-202; (b) Yates, B. F.; Bouma, W. J.; Radom, L. L. I. Am. Chem. Soc. 1984, 106, 5805-5808; (c) Yates, B. F.; Bouma, W. J.; Radom, L. L. Tetrahedron 1986, 42, 6225-6234.

2. Stirk, K. M.; Orlowski, J. C.; Leeck, D. T.; Kenttämaa, H. I. J. Am. Chem. Soc. 1992, 114, 8604-8606.

3. Smith, R. L.; Kenttämaa, H. I. J. Am. Chem Soc. 1995, 117. 1393-1396.

4. Smith, R. L.; Franklin, R. L.; Stirk, K. M.; Kenttämaa, H. I. J. Am. Chem. Soc. 1993, 115, 10348-10355.

5. Beasley, B. J.; Smith, R. L.; Kenttämaa, H. I. J. Mass Spectrom. 1995, 30, 384-385.
6. Marshall, A. G.; Wang, T. C. L.; Ricca, T. L. J. Am. Chem. Soc. 1985, 107, 7893-7897.

7. Leeck, D. T.; Stirk, K. M.; Zeller, L.; Kiminkinen, L. M.; Castro, L.; Vainiotalo, P.; Kenttämaa, H. I. I. Am. Chem. Soc. 1994, 116, 3028-3038.

8. (a) Stirk, K. M.; Kenttämaa, H. I. I. Phys. Chem. 1992, 96, 5272-5276; (b) Bartmess, J. E.; Georgiadis, R. M. Vacuum 1983, 33, 149 .

9. Su, T.; Chesnavich, W. J. I. Chem. Plyys. 1982, 76, 5183-5185.

10. Miller, K. J.; Savchik, J. A. I. Am. Chem. Soc. 1979, 101, 7206-7213.

11. (a) Newcomb, M. Tetrahedron 1993, 49, 1151-1176; (b) Newcomb, M.; Varick, T. R.; Ha, C.; Manek, M. B.; Yue, X. I. Am. Chem. Soc. 1992, 114, 8158-8163.

12. (a) Stirk, K. M.; Kenttämaa, H. I. I. Am. Chem. Soc. 1991, 113, 5880-5881; (b) Heinrich, N.; Koch, W.; Morrow, J. C.; Schwarz, H. J. Am. Chem. Soc. 1988, 110, 6332-6336; (c) Dass, C.; Gross, M. L. Org. Mass Spectrom. 1990, 25, 24-32.

13. Schweighofer, A.; Chou, P. K.; Nanayakkara, V.; Thoen, K. K.; Keck, H.; Kuchen, W.; Kenttämaa, H. l. J. Am. Chem. Soc., in press.

14. Smith, R. L.; Schweighofer, A.; Keck, H.; Kuchen, W.; Kenttämaa, H. I. J. Am. Chem. Soc. 1996, 118, 1408-1412.

15. Lias, S. G.; Bartmess, J. E.; Liebman, J. F.; Holmes, J. L.; Levin, R. D.; Mallard, W. G. J. Phys. Chemt. Ref. Data 1988, 17, Suppl. 1.

16. Bock, H.; Aygen, S.; Rosmus, P.; Solouki, B.; Weissflog, E, Chem. Ber. 1984, 117, 187-202.

17. Rosenstock, H. M.; Draxl, K.; Steiner, B. W.; Herron, J. T. J. Phys. Chem. Ref. Data 1977, 6, Suppl. 1. 